\title{
PHYSICO-CHEMICAL AND MICROBIOLOGICAL CHARACTERISTICS, SENSORY QUALITY AND ACCEPTABILITY OF NATIVE CHICKEN AND RABBIT SAUSAGE PRODUCED WITH CORN OIL, MARGARINE AND BEEF FAT
}

\author{
Hendronoto Arnoldus Walewangko Lengkey, Balia Roostita Lobo \\ Food Technology Department, Animal Husbandry, Universitas Padjadjaran, Indonesia
}

Received 17 November 2015; Received in revised form 10 May 2016; Accepted 28 May 2016

\begin{abstract}
In this paper, we evaluated the effect of certain oils or fats (corn oil, margarine and beef fat) on the physico-chemical, microbiological characteristics and sensory quality of native chicken and rabbit sausages as low fat sausages. The sausages were evaluated by physicochemical analysis of $\mathrm{pH}, \mathrm{a}_{\mathrm{w}}$, moisture content, protein and fat, TPC and Salmonella as microbiological characteristics, as well as flavor, juiciness and overall acceptability as sensory quality, and with regards to diversification of meat products in Indonesia. Three formulations for native chicken (FA) and rabbit (FB) sausages were prepared: FA1 and FB1 (with 10\% corn oil); FA2 and FB2 (with 10\% margarine): FA3 and FB3 (with $10 \%$ beef fat). Results indicated no significant difference $(\mathrm{p}<0.05)$ between the $\mathrm{pH}$ and $\mathrm{a}_{\mathrm{w}}$ values of native chicken and rabbit sausages using different fat sources. The moisture content was significantly different $(\mathrm{p}<0.05)$ both between the native chicken and rabbit sausages and the types of fat source (corn oil, margarine and beef fat) added. No effect on protein content was found both in native chicken and rabbit sausages. The lowest fat content was found in rabbit sausages $(18.79 \pm 0.70 \%)$ where corn oil was added as a fat source. Lowest TPC was also observed. Salmonella were not detected in any of the sausage groups. There was no significant difference $(p<0.05)$ in various sensory attributes. In conclusion, native chicken and rabbit meat seems to be a suitable alternative for low fat sausages production, particularly with corn oil as fat source.
\end{abstract}

Key words: native chicken sausages, rabbit sausages, corn oil, margarine, beef fat

\section{INTRODUCTION}

The potential of native chickens in Indonesia is big as egg and meat producers, with this sector expanding rapidly (1), while the chicken carcass fat content does not exceed $7.8 \%$ (2). Rabbit meat also contains only $7.4 \%$ fat. Rabbit meat is high in protein, but low in fat content. It has a low content of saturated fatty acid and tends to have low cholesterol. Thus, it is a highly nutritious meat and is suitable for special diets (3). Traditionally, native chicken is a common dish in Indonesia, while the same goes for rabbit in West Java. Native chicken and rabbit are cooked

Corresponding author: Prof. Hendronoto A. W. Lengkey, $\mathrm{PhD}$ E-mail address: lengkeyhendronoto@gmail.com

Present address: Food Technology Department, Animal Husbandry, Universitas Padjadjaran, Jl. Raya Bandung-Sumedang km 21, Jatinangor 45363, Indonesia

Phone: +628156075541

Copyright: (C) 2016 Lengkey H. This is an open-access article published under the terms of the Creative Commons Attribution License which permits unrestricted use, distribution, and reproduction in any medium, provided the original author and source are credited. Competing Interests: The authors have declared that no competing interests exist.

Available Online First: 10 June 2016

Published on: 15 October 2016

http://dx.doi.org/10.1515/macvetrev-2016-0087 as fried, grilled, or processed as satay, meat balls and sausages. Sausages are one of the oldest forms of processed food. Many sausage products provide a variety of fat and meats. The flesh of any food animal can be used in making sausages. The meat is halal covered not only with regards to the kinds of food consumed, but also concerning the conditions for their preparation and use. The native chicken and rabbit are halal when they are slaughtered according to Moslem rules. They are not stunned and are killed and bled simultaneously by one clean stroke of the knife blade applied to the throat of the animal. The sausage industry has brought about modification to recipes and procedures. The potential health risks associated with the consumption of high fat foods has led to the development of new formulations to modify traditional food products to contain less fat (4). Several alternative strategies have been used to produce low fat sausages, such as the substitution of saturated fat with vegetable oil $(5,6,7)$. Corn oil and margarine represent vegetable oil or fat. In Indonesia corn and coconut are abundant, so there is no problem to use them as animal fat replacement. 
Corn oil and margarine have lower fat content than animal fat. Native chicken and rabbit are halal and a good choice for Indonesian dishes. Studies have explored possible fat reduction in sausages, using partial fat replacement by lean meat as a formulation strategy. However, these reformulation processes often increase the toughness due to higher water loss during processing. Visual differences in the product appearance also occur as there is less granulated fat, as the fat content is reduced (8). The World Health Organization have drawn up the following nutritional recommendations, fat should provide between $15-30 \%$ of the calories in the diet, saturated fat should not provide more than $10 \%$ of these calories and cholesterol intake should be limited to $300 \mathrm{mg} /$ day. This resulted in an increased demand for fat reduced and low-fat meat products.

Fat is important for sausages, because it acts as a source of essential fatty acids, fat soluble vitamins and constitutes a source of energy. Fat also contributes to the flavor, texture, juiciness, which determine the quality and acceptability of sausages (4). The substitution of animal fat with vegetable oils has been suggested to improve the fatty acid profile and to decrease the cholesterol levels of meat products, with several vegetable oils already having been used as fat substitutes. The development of products, including sausages, containing raw poultry meat is complicated by issues that could become serious public health risks, such as the presence of Salmonella spp. in the chicken carcass (9).

The food industry is mostly concerned with food pathogens, Listeria monocytogenes, Salmonella spp., Campylobacter and Escherichia coli. Listeria monocytogenes has been described in several sausages product (10), as a result of unsuccessful proper processing, or due to high initial contamination of the raw material.

The objectives of this study was to determine the physico-chemical and microbiological characteristics, as well as the sensory quality and acceptability of native chicken and rabbit sausages; to evaluate the quality characteristics of formulation process that contains low fat by using healthier ingredients, such as corn oil and margarine. Furthermore, it is concerned with the diversification of meat products in Indonesia.

\section{MATERIAL AND METHODS}

\section{Raw Materials}

Native chickens breast fillets, rabbit meats, corn oil, margarine and beef fat were used in these experiments. Native chicken meat and rabbit meat was purchased from traditional farm in Lembang, 194
West Java, Indonesia. The meat was kept overnight in a refrigerator and manually deboned. Each meat was deboned into portions weighing $3 \mathrm{~kg}$ and immediately stored at $4^{\circ} \mathrm{C}$, The other materials were purchased from a local wholesaler, Griya Supermarket in Jatinangor, West Java.

\section{Formulations}

Three formulations of native chicken (FA) and rabbit (FB) sausages were prepared, FA1 and FB1 (with 10\% corn oil); FA2 and FB2 (with 10\% margarine) and FA3 and FB3 (with $10 \%$ beef fat); this was repeated five times in a completely randomized design. Physico-chemical $\left(\mathrm{pH}, \mathrm{a}_{\mathrm{w}}\right.$, moisture content, protein and fat), microbiological (TPC and Salmonella) and sensory analyses (flavor, juiciness and overall acceptability) were performed on production day (day 0 ).

\section{Sausage Preparation}

In Table 1, the formulation of the sausages is presented. Each sausage was produced from $1 \mathrm{~kg}$ native chicken meat $(100 \%)$ and $1 \mathrm{~kg}$ rabbit meat $(100 \%)$. The meat was chilled overnight at $4^{\circ} \mathrm{C}$, and minced separately in the food processor. Afterwards, each minced meat was separated into three parts and then each part was added $10 \%$ corn oil, margarine and beef fat successively. The beef fat was frozen, tempered at $-2^{\circ} \mathrm{C}$, chopped and mixed in a rotating bowl meat cutter before added to the minced meat. The sausage batter was added with the same amount of ingredients: $10 \%$ flour as filler, $2 \%$ salt, $2 \%$ sugar, $0.1 \%$ garlic powder, $0.2 \%$ white pepper, and then mixed carefully. The resultant mixture was filled in casings, and then hung on sticks. Sampling was carried out on production day.

\section{Physico-chemical analysis}

The physico-chemical analysis $\left(\mathrm{pH}, \mathrm{a}_{\mathrm{w}}\right.$, moisture content, protein and fat), determined according to AOAC standard procedures (11), was performed in duplicate. For the determination of $\mathrm{pH}, 10 \mathrm{~g}$ of each sample was homogenized with distilled water in the ratio of 1:10. The homogenate was subjected to a $\mathrm{pH}$ test using a $\mathrm{pH}-$ meter (3310 Jenway $\mathrm{pH}$ meter). The $\mathrm{pH}$ value was determined on production days by taking the average of two readings. Water Activity System apparatus (Aqualab lite) was used to measure the water activity $\left(a_{w}\right)$. The $a_{w}$ values were determined in duplicate in order to optimize the weights of samples at $25^{\circ} \mathrm{C}$ until equilibrium was reached. The chemical composition of the sausage with regards to moisture, protein and fat content was determined as per AOAC (11), using a hot air oven (JEIO tech IB-05G), Kjeldahl and soxhlet extraction apparatus, respectively. 
Physico-chemical and microbiological characteristics, quality and acceptability of chicken and rabbit sausage

Table 1. Formulation and treatments of sausages with various fat and oil

\begin{tabular}{lcccccc}
\hline & \multicolumn{3}{c}{ Native Chicken Sausages } & \multicolumn{3}{c}{ Rabbit Meat Sausages } \\
\cline { 2 - 6 } Ingredients & \multicolumn{7}{c}{ FA-1 } & FA-2 & FA-3 & FB-1 & FB-2 & FB-3 \\
\cline { 2 - 6 } & $1.00 \mathrm{~kg}$ & $1.00 \mathrm{~kg}$ & $1.00 \mathrm{~kg}$ & $1.00 \mathrm{~kg}$ & $1.00 \mathrm{~kg}$ & $1.00 \mathrm{~kg}$ \\
Raw meat & $0.10 \mathrm{~kg}$ & $0.10 \mathrm{~kg}$ & $0.10 \mathrm{~kg}$ & $0.10 \mathrm{~kg}$ & $0.10 \mathrm{~kg}$ & $0.10 \mathrm{~kg}$ \\
Fat/Oil* & $0.10 \mathrm{~kg}$ & $0.10 \mathrm{~kg}$ & $0.10 \mathrm{~kg}$ & $0.10 \mathrm{~kg}$ & $0.10 \mathrm{~kg}$ & $0.10 \mathrm{~kg}$ \\
Flour & $0.02 \mathrm{~kg}$ & $0.02 \mathrm{~kg}$ & $0.02 \mathrm{~kg}$ & $0.02 \mathrm{~kg}$ & $0.02 \mathrm{~kg}$ & $0.02 \mathrm{~kg}$ \\
Sugar & $0.02 \mathrm{~kg}$ & $0.02 \mathrm{~kg}$ & $0.02 \mathrm{~kg}$ & $0.02 \mathrm{~kg}$ & $0.02 \mathrm{~kg}$ & $0.02 \mathrm{~kg}$ \\
Garlic powder & $0.001 \mathrm{~kg}$ & $0.001 \mathrm{~kg}$ & $0.001 \mathrm{~kg}$ & $0.001 \mathrm{~kg}$ & $0.001 \mathrm{~kg}$ & $0.001 \mathrm{~kg}$ \\
White pepper & $0.002 \mathrm{~kg}$ & $0.002 \mathrm{~kg}$ & $0.002 \mathrm{~kg}$ & $0.002 \mathrm{~kg}$ & $0.002 \mathrm{~kg}$ & $0.002 \mathrm{~kg}$ \\
\hline
\end{tabular}

Notes : ${ }^{*} 1$ - corn oil, $* 2$ - margarine, $* 3$ - beef fat

Microbiological analysis

To evaluate the microbiological characteristics on days 0 , three sausages per batch were used. Aliquots of $25 \mathrm{~g}$ were collected, homogenized with $225 \mathrm{~mL}$ of $0.1 \%$ peptone water, and serially diluted on a decimal scale. The microbiological analyses were performed in duplicate. The data was transformed into alogarithm of the number of colony-forming units $\left(\mathrm{cfug}^{-1}\right)$ (12). Total Plate Count (TPC) for determination of the number of viable microorganisms in the sample (13), and for Salmonella as per AOAC (11).

\section{Sensory analysis}

The sensory characteristics for native chicken and rabbit sausages regarding flavor, juiciness and overall acceptability was evaluated by 30 students that had previous experience in sausages evaluation. The coded formulations were evaluated in randomized fashion, as per a hedonic scale of 9 points (14). The presented data are the mean values of the panelist.

\section{Statistical analysis}

The experiment, used a completely randomized design and was repeated five times. All analyses were performed in duplicate, and the data was evaluated through an analysis of variance (ANOVA). The means were compared by Tukey's test at a confidence level of $5 \%(p \leq 0,05)$.

\section{RESULTS}

\section{Physico-chemical characteristics}

The results obtained of various physicochemical characteristic $\left(\mathrm{pH}, \mathrm{a}_{\mathrm{w}}\right.$, moisture content, protein and fat) of native chicken and rabbit meat sausages are shown in Table 2. The initial mean $\mathrm{pH}$ values of the sausages (both native chicken and rabbit) were between $5.49-5.66$ with no significant differences between the six sausages. There was significant difference $(p<0.05)$ between $a_{w}$ of native chicken and rabbit sausages with the use of different fat sources.

Table 2. Physico-chemical characteristic of native chicken and rabbit sausages

\begin{tabular}{lcccccc}
\hline Treatments & \multicolumn{5}{c}{ Formulation } \\
\cline { 2 - 7 } & FA1 & FA2 & FA3 & FB1 & FB2 & FB3 \\
\hline pH & $5.49 \pm 0.09^{\mathrm{a}}$ & $5.63 \pm 0.05^{\mathrm{a}}$ & $5.61 \pm 0.05^{\mathrm{a}}$ & $5.51 \pm 0.05^{\mathrm{a}}$ & $5.65 \pm 0.05^{\mathrm{a}}$ & $5.66 \pm 0.02^{\mathrm{a}}$ \\
$\mathbf{a}_{\mathbf{w}}$ & $0.83 \pm 0.01^{\mathrm{a}}$ & $0.84 \pm 0.01^{\mathrm{a}}$ & $0.87 \pm 0.01^{\mathrm{b}}$ & $0.84 \pm 0.01^{\mathrm{a}}$ & $0.86 \pm 0.01^{\mathrm{b}}$ & $0.89 \pm 0.01^{\mathrm{c}}$ \\
Moisture & $60.30 \pm 1.50^{\mathrm{c}}$ & $61.52 \pm 1.60^{\mathrm{d}}$ & $64.03 \pm 1.60^{\mathrm{e}}$ & $50.07 \pm 1.70^{\mathrm{a}}$ & $51.20 \pm 1.60^{\mathrm{b}}$ & $51.52 \pm 1.80^{\mathrm{b}}$ \\
Protein & $19.02 \pm 0.50^{\mathrm{b}}$ & $18.48 \pm 0.48^{\mathrm{a}}$ & $19.05 \pm 0.49^{\mathrm{b}}$ & $18.37 \pm 0.48^{\mathrm{a}}$ & $18.05 \pm 0.45^{\mathrm{a}}$ & $19.22 \pm 0.47^{\mathrm{b}}$ \\
Fat & $19.60 \pm 0.70^{\mathrm{ab}}$ & $19.51 \pm 0.90^{\mathrm{ab}}$ & $19.38 \pm 0.80^{\mathrm{ab}}$ & $18.79 \pm 0.70^{\mathrm{a}}$ & $20.00 \pm 0.70^{\mathrm{ab}}$ & $20.29 \pm 0.80^{\mathrm{b}}$ \\
\hline
\end{tabular}

Note: Means \pm SD in the same row followed by different lowercase letters indicates significant differences $(p \leq 0.05)$ among formulations $(\mathrm{n}=9$, each). Dry basis values. The physico-chemical analyses were performed in duplicate

Formulations: FA: native chickens sausage, FB: rabbit sausages, 1: 10\% corn oil, 2: $10 \%$ margarine, $3: 10 \%$ beef fat 
Lengkey H.A.W. and Lobo B.R.

Table 3. Microbiological characteristics (Total Plate Counts and Salmonella in the sausages)

\begin{tabular}{lcccccc}
\hline Parameters & \multicolumn{5}{c}{ Formulation } \\
\hline & FA1 & FA2 & FA3 & FB1 & FB2 & FB3 \\
\cline { 2 - 7 } TPC & $5.25 \pm 0.01^{\mathrm{b}}$ & $5.33 \pm 0.01^{\mathrm{c}}$ & $5.37 \pm 0.02^{\mathrm{c}}$ & $5.10 \pm 0.05^{\mathrm{a}}$ & $5.20 \pm 0.05^{\mathrm{b}}$ & $5.30 \pm 0.06^{\mathrm{c}}$ \\
Salmonella & - & - & - & - & - & - \\
\hline
\end{tabular}

Note: Dry basis values. The microbiological analyses were performed in duplicate

Formulations: FA: native chickens sausage, FB: rabbit sausages, 1: $10 \%$ corn oil, $2: 10 \%$ margarine, $3: 10 \%$ beef fat

Data presented in Table 2. shows that the physicochemical parameters ( $\mathrm{pH}$ and $\mathrm{a}_{\mathrm{w}}$ ) in both sausages (native chicken and rabbit) were quite similar. The small differences between native chicken and rabbit sausages with same formulations was not a significant difference in $\mathrm{pH}$, but has significancy in $\mathrm{a}_{\mathrm{w}}$. The $\mathrm{pH}$ of the sausages was significantly lower $(\mathrm{p}<0.05)$, both in native chicken sausages; between $5.49 \pm 0.09$ to $5.63 \pm 0.05$; and also in rabbit sausages, between $5.51 \pm 0.05$ to $5.66 \pm 0.02$. The $\mathrm{a}_{\mathrm{w}}$, varied significantly in all formulations; in native chicken sausage it was between $0.83 \pm 0.01$ to $0.87 \pm 0.01$; and in rabbit sausages it was between $0.84 \pm 0.01$ to $0.89 \pm 0.01$. Lowest $\mathrm{a}_{\mathrm{w}}$ values of native chicken sausages $(0.83 \pm 0.01)$ and rabbit sausage $(0.84 \pm 0.01)$ were found in the group where corn oil was used, while the highest values of native chicken sausage $(0.87 \pm 0.01)$ and rabbit sausage $(0.89 \pm 0.01)$ were observed in groups having beef fat as fat source. sausages products, including that contained native chicken and rabbit meat in all of the six formulations, All samples were free of Salmonella spp.

Total Plate Count was observed in all of the six formulation of sausages on the day of processing. In native chicken sausages between $5.25 \pm 0.01$ (with corn oil) to $5.37 \pm 0.02$ (beef fat) and in rabbit sausages between $5.10 \pm 0.05$ (with corn oil) and $5.30 \pm 0.06$ (with beef fat).

\section{Sensory analysis}

No obvious differences have been found in sensory analysis between the sausages (native chicken and rabbit sausages) and also in fat formulations $(10 \%$ corn oil, margarine and beef fat). Even fat contributes to the flavor and juiciness which determine the quality and acceptability of sausages, but the acceptance of all sausages in this experiment was non-significant $(p<0.05)$. The

Table 4. Sensory analysis of native chicken and rabbit sausages

\begin{tabular}{lcccccc}
\hline Parameters & \multicolumn{7}{c}{ Formulation } \\
\hline \multirow{2}{*}{ Flavor } & FA1 & FA2 & FA3 & FB1 & FB2 & FB3 \\
\cline { 2 - 7 } Juiciness & $7.70+0.40$ & $7.80+0.66$ & $7.70+0.87$ & $7.60+0.40$ & $7.80+0.65$ & $7.60+0.60$ \\
Acceptability & $7.60+0.66$ & $7.70+0.80$ & $7.70+0.60$ & $7.70+0.60$ & $7.70+0.80$ & $7.70+0.66$ \\
\hline
\end{tabular}

Note: The presented data are mean values of the panelist. The data were non significance.

Formulations: FA: native chickens sausage, FB: rabbit sausages, 1: 10\% corn oil, 2: $10 \%$ margarine, $3: 10 \%$ beef fat

The chemical composition of the native chicken and rabbit sausages - the moisture content of native chicken sausages was between $60.30 \pm 1.50$ to 64.03 \pm 1.60 , while for rabbit sausage it was between $50.07 \pm 1.70$ to $51.52 \pm 1.80$. The protein content of native chicken sausage varied between $18.48 \pm 0.48$ to $19.05 \pm 0.49 \%$. and that of rabbit sausage from $18.05 \pm 0.45$ to $19.22 \pm 0.47 \%$. For fat content, the lowest was found in rabbit sausage $(18.79 \pm 0.70 \%)$, wherein corn oil was added as a fat source.

\section{Microbiological characteristics}

The microbial characteristics of native chickens and rabbit sausages are presented in Table 3. The 196 acceptability was around seven (7.69 to 7.73), indicating that the panelists moderately liked the sausages. Although the sensory acceptability depended on some preference of the panelist, from the acceptance of the sausages, it can be concluded that both native chickens and rabbit sausages were accepted by the panelist.

\section{DISCUSSION}

Although there were differences between the two meat sausages (native chicken and rabbit) with three type of fat (margarine, corn oil and beef fat) in 
Physico-chemical and microbiological characteristics, quality and acceptability of chicken and rabbit sausage

the sausages; they were not statistically significant for $\mathrm{pH}$. The $\mathrm{pH}$ value of both native chicken and rabbit (between $5.49 \pm 0.09$ to $5.63 \pm 0.05$ and $5.51 \pm 0.05$ to $5.66 \pm 0.02$ ) was even lower in all treatment groups, though they were well within the normal range, the normal $\mathrm{pH}$ of meat products ranged from 4.8-6.8, while the $\mathrm{pH}$ of fresh sausage was at least $5.5(10,15)$. The low $\mathrm{pH}$ is desirable in order to assure the stability of microorganisms in the sausages, especially when the sausages are stored at room temperature. This condition was supported by (16). Findings were also reported in the experiment on hurdle treated pork sausages (17) where the $\mathrm{pH}$ ranged from 6.1 to 6.4 , depending on the sample. The lower $\mathrm{pH}$ value of sausages could be attributed to the low $\mathrm{pH}$ of native chicken and rabbit meat.

Lowest $\mathrm{a}_{\mathrm{w}}$ values were recorded in both sausages where corn oil was used, which showed that corn oil as a fat source is desirable in sausages because of reduced $a_{w}$ values. Sausages having low $a_{w}$ or combination of low $\mathrm{pH}$ and reduced $\mathrm{a}_{\mathrm{w}}$ had better microbial stability (18). It was also reported that $\mathrm{pH}$ and water activity are important factors controlling the microbiological safety of foods (19).

Fat also contributes to the flavor, texture, juiciness, which determine the quality and acceptability of sausages. The differences were only due to the modification of the sausages formulation. Obtaining lower fat sausages, through using vegetable oils, will increase the water content in the sausages. The moisture content in rabbit sausages is lower than the moisture content in native chicken sausages, because of the fat content of rabbit meat being higher than in the native chicken. The lower fat content was due to the fat content of meat. Rabbit meat is high in protein and low in fat (7.4\%) (3). It also has a low content of saturated fatty acid, thus it tends to have a low cholesterol. Consequently, it is a highly nutritious meat, suitable for special diets. Native chicken carcass has low fat, and the fatness did not exceed 7.8\% (2). Many studies using vegetable oil as substitutes for animal fat have reported formulations for sausages prepared with different types of oils (corn oil, and margarine) and also using beef fat. Both results for products with corn oil and margarine were lower than the animal fat, in native chicken sausage and rabbit sausages, respectively. These results indicated that vegetable oils could be used as animal fat replacers in low fat sausages. This is consistent with research which has used oil with healthier lipid combination in water emulsions as pork back-fat replacers in low-fat frankfurters (20). Animal fat has higher fat percentage than vegetable oil (8), so vegetable oil could be used to improve the fat content of sausages, because it could reduce the fat content. The lowest fat content of rabbit sausages wherein corn oil was added as a fat source, may be attributed to the low fat content in rabbit meat compared to native chicken meat (21). Corn oil has been reported to contain less fat content than beef fat $(8,22)$. This suggests that vegetable oil could be used as animal fat replacer in the preparation of low fat sausages. This condition also could be used as an approach for development of functional meat products (20). With regards to the microbiological characteristics, they were detect for Salmonella and total plate count. In all formulations Salmonella was not detected, because the $\mathrm{pH}$ of the sausages (between 5.49 to 5.66) should be sufficient to inhibit the growth of Salmonella. The $\mathrm{pH}$ of FA1 (5.49) and $\mathrm{a}_{\mathrm{w}}(0.83)$, also in FA2 the $\mathrm{pH}$ and $\mathrm{a}_{\mathrm{w}}$, was even higher (5.63 and 0.84) and in FA3 the pH was 5.61 and the $\mathrm{a}_{\mathrm{w}}$ 0.87. In this condition Salmonella was inhibited. This is in line with other studies, that $\mathrm{pH} 6.6$ to 8.2 could inhibit the growth of Salmonella (7). Minimum $\mathrm{pH}$ of 5.4 will inhibit the Salmonella. As the $\mathrm{pH}$ decreases to minimum values, Salmonella needs higher $\mathrm{a}_{\mathrm{w}}$ for growth. In this study, the $\mathrm{a}_{\mathrm{w}}$ is between 0.83 to 0.89 . The results show that using poultry and rabbit meat in sausage production is possible, from the stand point of microbiological characteristics. During sensory analysis, all sausages formulations indicated no significant differences. The results indicated that using corn oil, margarine and beef fat in sausage production did not affect the acceptability of the products. This is in line with the fact that reducing oil content did not affect product acceptability (9).

\section{CONCLUSION}

It can be concluded that native chicken and rabbit meat seem to be suitable for the production of low fat sausages using corn oil, margarine and beef fat. Based on the results obtained regarding the physicochemical, microbiological characteristics and the acceptability of the use of corn oil and margarine, they can be used for the processing of native chicken and rabbit sausage; also this will represent a diversification of traditional dishes in Indonesia. The results of this study suggest that using some fat sources $(10 \%$ corn oil, $10 \%$ margarine and $10 \%$ beef fat) should be considered in native chicken and rabbit sausages formulations. The sensory evaluation was similar for both sausages. Furthermore, the $a_{w}$ (water activity) varied significantly $(\mathrm{p}<0.05)$ in both native chicken and rabbit sausages with the use of different fat sources.

In comparison, the $\mathrm{a}_{\mathrm{w}}$ value results were not significantly different between the sausages made 
from both native chicken and rabbit meat. It means that using native chicken or rabbit for production of sausages will result in no significant differences in the physico-chemical characteristics. The small differences may be usual as consequences of the difference between the meats (native chicken and rabbit).

\section{REFERENCES}

1. Buckle, K. A. (1978). Meat science and technology, In: K.A. Buckle, R. A. Edwards, G. H. Fleet and M. Wootton (Eds.), Food Science (pp. 143-167). Australian Vice-Chancellor's Committee.

2. Muir, W.M. (2003). S. E. Aggrey (ed.), Poultry genetics, breeding and biotechnology (p.58). CABI Publishing. Wallingford. UK.

3. McNitt, J. I., Patton, N. M., Lukefahr, S. D., Cheeke, P. R. (2011). Rabbit production. 8th ed. (pp. 453 - 475). Paperback CABI. Wallingford, UK.

4. Olivares, A., Navarro, J. L., Salvador, A., Flores, M. (2010). Sensory acceptability of slow fermented sausages based on fat content and ripening time. Meat Sci. $86,251-257$.

http://dx.doi.org/10.1016/j.meatsci.2010.04.005 PMid:20510528

5. Koutsopoulos, D. A., Koutsimanis, G. E., Blougas, J. G. (2008). Effect of carrageenan level and packaging during ripening on processing and quality characteristics of low-fat fermented sausages produced with olive-oil. Meat Sci. 79 (1) : 188 - 197. http://dx.doi.org/10.1016/j.meatsci.2007.08.016 PMid:22062612

6. Ospina E.J.C., Cruz-S, A., Perez-Alvarez, J.A., Fernandez-Lopez, J. (2010). Development of Combinations of chemically modified oils as pork backfat substitutes in sausages formulations. Meat Sci. 84(3): 491-497.

http://dx.doi.org/10.1016/j.meatsci.2009.10.003 PMid:20374815

7. Lengkey, H. A. W., Suryaningsih, L., Sembor, S., Balia, R. L. (2014). The effect of various fat on rabbit sausages chemical properties. Prosiding Seminar Nasional Peternakan Berkelanjutan 6. November, 18-19, (pp. 310-315) Fakultas Peternakan Universitas Padjadjaran, Bandung, Indonesia (in Indonesian).

8. Jimenez-Colmenero, F., Triki, M., Herrero, A. M., Rodriguez-Salas, L. (2013). Healthy oil combination stabilized in a konjac matrix as pork fat replacement in low-fat, PUFA-enriched, dry fermented sausages. LWT-Food Science and Technology 51, 158 - 163. http://dx.doi.org/10.1016/j.lwt.2012.10.016
9. Menegas, L. Z., Pimentel, T. C., Gracia, S., Prudencio, S. H. (2013). Dry-fermented chicken sausage produced with inulin and corn oil: Physicochemical, microbiological, and textural characteristics and acceptability during storage. Meat Sci. 93, 501- 506.

http://dx.doi.org/10.1016/j.meatsci.2012.11.003 PMid:23273457

10. Rossi, L. P. R., Almeida, R. C. C., Lopes, L. S., Figueiredo, A. C. L., Ramos, M. P. P., Almeida, P. F. (2010). Occurrence of Listeria spp. in Brazilian fresh sausage and control of Listeria monocytogenes using bacteriophage P100. Food Control 22, 954 - 958. http://dx.doi.org/10.1016/j.foodcont.2010.12.001

11. AOAC, 1990. Official methods of analysis. 15th ed. Association of official analytical chemists (pp. 931-948), Arlington, Virginia, USA.

12. Maturin, L., Peeler, J. T. (2001). Bacteriological analytical manual. Chapter 3. Aerobic plate count. Available at: http://www.fda.gov/Food/ FoodScienceResearch/LaboratoryMethods/ ucm063346.

13. Heinz, G., Hautzinger, P. (2007). Meat processing technology. FAO Regional office for Asia and the Pacific. Bangkok p. 335.

14. Larmond, E. (1977). Laboratory methods for sensory evaluation of food. Research branch Canada department of agriculture. Publication 11637. p. 57.

15. Cocolin, L., Rantsiou, K., Iacumin, L., Urso, R., Cantoni, C., Comi, G. (2004). Study of the ecology of fresh sausages and characterization of population of lactic acid bacteria by molecular method. J.Appl. Environ. Microbiol. 70 (4): 1883 - 1894.

http://dx.doi.org/10.1128/AEM.70.4.1883-1894.2004 PMCid:PMC383013

16. Fernando-Lopez, J., Sendra, E., Sayas-Barbera, E., Navarro, C., Perez-Alvarez, J. A. (2008). Physicochemical and microbiological profiles of salchichon (Spanish dry-fermented sausage) enriched with orange fibre. European Food Research and Technology 221, 410-417.

17. Thomas, R., Anjaneyulu, A. S. R., Kondaiah, N. (2010). Quality of hurdle treated pork sausages during refrigerated $(4+10 \mathrm{C})$ storage. J Food Sci Technol. 47 (3): $266-272$.

http://dx.doi.org/10.1007/s13197-010-0041-1 PMid:23572635 PMCid:PMC3551018

18. International Commission on Microbiological Specifications for Food. (2002). Microorganisms in foods 6.Microbial ecology of food commodities. Aspen Publ. Inc. Gaithersburg. Maryland.

19. Wijtes, T., Mc Clure, P.J., Zwietering, M.H., Roberts, T. A. (1993). Modeling bacterial growth of Listeria monocytogenes as a function of water activity, $\mathrm{pH}$ and temperature. Int. J. Food Microbiol. 18, 139-149. http://dx.doi.org/10.1016/0168-1605(93)90218-6 
Physico-chemical and microbiological characteristics, quality and acceptability of chicken and rabbit sausage

20. Delgado-Pando, G., Cofrades, S., Ruiz-Capillas, C., Jimenez-Colmenero, F. (2010). Healthier lipid combination oil-in water emulsions prepared with various protein systems: an approach for development of functional meat products. European Journal of Lipid Science and Technology 112(7): $791-801$. http://dx.doi.org/10.1002/ejlt.200900234

21. Nistor, E., Bampidis, V.A., Pacala, N., Pentea, M., Tozer, J., Prundeanu, H. (2013). Nutrient content of rabbit meat as compared to chicken, beef and pork meat. J. Anim. Prod. Adv. 3, 172-176.

http://dx.doi.org/10.5455/japa.20130411110313
22. Baiao, N.C., Lara, L.J.C. (2005). Oil and fat in broiler nutrition. Brazil J. Poult. Sci. 7, 129-141.

http://dx.doi.org/10.1590/s1516-635x2005000300001

Please cite this article as: Lengkey H.A.W., Lobo B.R. Physico-chemical and microbiological characteristics, sensory quality and acceptability of native chicken and rabbit sausage produced with corn oil, margarine and beef fat. Mac Vet Rev 39 (2): $193-199$. http://dx.doi.org/10.1515/macvetrev-2016-0087 